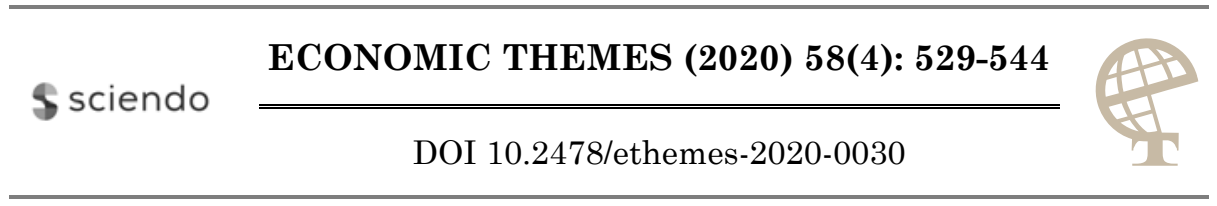

\title{
EVALUATING ICT USAGE IN ENTERPRISES IN EUROPE: TOPSIS APPROACH
}

\author{
Nikola Vasilić \\ University of Belgrade, Institute "Mihajlo Pupin", Serbia \\ $\triangle$ nikola.vasilic@pupin.rs \\ Dušica Semenčenko \\ University of Belgrade, Institute "Mihajlo Pupin", Serbia \\ $\square$ dusica.semencenko@pupin.rs \\ Sanja Popović-Pantić \\ University of Belgrade, Institute "Mihajlo Pupin", Serbia \\ $\square$ sanjap.pantic@pupin.rs
}

UDC

004:007(4)

Original scientific paper

Received: 06.11.2020 Accepted: 26.12.2020

\begin{abstract}
The main objective of the paper is to evaluate ICT usage in enterprises in 31 European countries. For that purpose, ICT usage in enterprises index (ICTEI) was developed using the TOPSIS approach based on the entropy method. Subsequently, having used the cluster analysis, countries were classified into clusters according to the observed indicators of ICT usage. Results show that Finland, Denmark, Norway, Sweden and Ireland are the top 5 countries when the advanced ICTs are prioritized. Based on the k-means clustering, Finland is a leader in a cluster of a very high ICT usage in enterprises and it is followed by Denmark, Norway, and Sweden. The cluster of high ICT usage in enterprises includes Ireland, Netherlands, Slovenia, Spain, and United Kingdom. Finally, the countries characterized by moderate and modest ICT usage are positioned in the remaining two clusters. The results of this research will facilitate the perception of a country's position in relation to others, but will also signal the need to take measures to strengthen the ICT capacity of the business sector in the countries with a low value of ICTEI.
\end{abstract}

Keywords: ICT, ICT usage in Enterprises Index - ICTEI, TOPSIS, Entropy method, Multi-criteria Decision Making, Cluster analysis.

JEL classification: C39, C44, D20.

* The research presented in this paper was funded by the Ministry of Education, Science and Technological Development of Serbia. 


\section{Introduction}

Every company, according to the activity it performs, has some influence on the socio-economic development of the country in which it operates. The business sector undoubtedly makes an exceptional contribution to the growth of gross domestic product. Production volume and output quality, the degree of innovation of companies, in terms of using alternative inputs, creating new products, providing services in a non-traditional way, etc. they largely trace the direction and dynamics of the country's economic development. The level at which the business sector as a whole, and each company individually, will be positioned regarding the aforementioned performance, depends on their ability to adapt and adapt to the tendencies characteristic of the new era of economy, known as the knowledge-based economy. The "naked eye" elusive development of ICT in the last two decades is the backbone of the knowledge-based economy and is an imperative for its progress. ICT penetrates all pores of society, changing the way of life and business philosophy, which motivates researchers from different fields to analyze the role of ICT, especially in business, in terms of considering aspects of business in which ICT would cause significant positive changes and examining implications. The use of ICT causes diverse repercussions on business operations and on the national economy. Since the purpose of this paper is not to analyze the impact of ICT use on business and the economy, the benefits of ICT use will only be briefly listed below, with an emphasis on innovation, which is a major driver of growth and development in the $21^{\text {st }}$ century.

Adoption and comprehensive use of ICTs are key factors in business strategy development, creating the conditions that stimulate creativity and innovation development (Ongori \& Migiro, 2010). Innovation represents a new way of organizing business, which can be significantly improved by using ICTs (Haseeb, 2015). Therefore, the most developed and innovative organizations are those that use ICTs to facilitate and drive innovation in business processes and products and services (Arvanitis et al., 2013).

The use of different types of ICTs in business enables inconceivable and diverse opportunities which were unimaginable two decades ago for companies to make progress. For example, the use of CRM software allows the analysis of various data concerning relations and transactions with customers (Kleis et al., 2012), based on which some new needs can be identified that could be met by some modification of the existing or development of a completely new product. Better knowledge of customer needs and reduced order processing time provided by ICTs based software solutions, such as ERP, CRM and similar, make it easier for firms to offer new customized products and services, which will lead to improved customer response (Ansari \& Mela, 2003). Thanks to ICTs, the rapid response of companies in terms of recognizing, adopting and incorporating newly identified customer requirements into the product, will have very noticeable reflections on the customer satisfaction 
and loyalty, as important pillars of sustainable company profitability. Similar effects are achieved by using social media (Hitchen et al., 2017) and websites (Spiezia, 2011) in business. It has been shown that the number of web facilities increases the probability to introduce a new product for the manufacturing firms (five countries out of eight) and also for the service firms (six countries out of seven). The effect of ICT usage on the probability to introduce a new product in services mainly occurs through new services (Spiezia, 2011). By reorienting from traditional trade to online sales and purchases, i.e. e-commerce, companies achieve numerous savings. E-commerce reduces the need for a large number of retail facilities, and, thus, consequently for labour. By reducing the number of intermediaries between a seller and a buyer, ecommerce makes the supply chain much more efficient. In addition, e-sales and epurchases reduce administrative costs, as they eliminate the need for paper-based supporting documentation, but more importantly, inventory costs will be reduced.

ICTs enable that the physical distance of key stakeholders is no longer an obstacle in the process of information exchange and knowledge creation, which certainly increases the probability of success in the innovation process. Also, ICTs ensure more efficient communication within the organization itself and between physically distant parts of the organization, which can be reflected in reducing operating costs and raising productivity.

The use of ICT brings numerous benefits to companies through the improvement of production and business processes, which will further have a positive impact on the functioning of the entire economy. There are different approaches in the literature to explaining how ICTs contribute to economic progress (Smith, 2002). According to the first approach, the emergence of new, ICT-based sectors, including the ICTproducing sector, contributes to a more dynamic economic growth. Within this approach, two sources of economic growth stand out. New ICT-based sectors achieve higher growth rates of added value, productivity and higher levels of income, which itself is a source of growth for the national economy. By creating new inputs and/or production methods that generate higher levels of productivity, ICT-based sectors generate changes in other sectors of the economy, mostly in a positive direction. The second approach, according to which ICTs are viewed as a new type of capital good, is based on the assumption that the increased investment in ICT will lead to the increased labour productivity and overall factor productivity. However, there is a third potential indirect growth impact - spillover effects. When the spillover effects of technological advances from industries producing ICT to industries using ICT takes place, an increase in total factor productivity can be achieved (Jorgensen, Ho \& Stiroh, 2002; van Ark, 2002).

The previously elaborated benefits that companies and national economies have from the use of ICT require constant monitoring and evaluation of the use of ICT by decision makers. This is especially important for economic policy makers on whom the ICT capacity of the business sector depends to a certain extent, and, in general, the spread of ICT throughout society. 
There is a wide range of indicators that policy makers can use to monitor the situation in the field of ICT. Most of the indicators, which cover different areas of ICT, have been developed by Eurostat. As these are a large number of individual indicators, policy makers may have some difficulty in drawing clear conclusions based on their analysis. Therefore, and taking into account the importance of ICT for growth and development, the aim of this research is to create a composite index of ICT usage in enterprises. This index should alleviate the diagnose of the situation in the domain of ICT usage in enterprises, compared to finding a common trend in many single indicators. Also, the advantage of using a composite index consists mainly of the simplicity of the results (individual ranking) and the ease with which it is possible to compare different units. Of course, it is indisputable that, in any case, it is necessary to analyze individual indicators, i.e. the structure of the composite index, in order to identify segments within ICT in which there are weaknesses.

In the first part of the empirical research, countries were ranked according to the ICT usage in enterprise using TOPSIS multi-criteria analysis method. In the second part, the cluster analysis was used to classify countries into clusters according to the results of TOPSIS.

\section{Methodology}

\subsection{Steps in creating ICT usage in enterprises index (ICTEI)}

\subsubsection{Selection of indicators and missing values imputation}

The evaluation of the ICT usage in enterprises in European countries was performed on the basis of data available on the Eurostat website (section: Digital economy and society; subsection: ICT usage in enterprises). A list of indicators used in the paper is presented in Table 1.

The data for 2019 were used to the greatest extent for the purposes of the evaluation of ICT usage in enterprises. For indicators C23, C42, C43 and C44 data for 2019 are not available. Thus, the data for 2017 were used for indicator C23 and for other three indicators the data for 2018 were used. Also, for some countries data on certain indicators are not available for 2019. For example, in the case of Malta data for 2017 were used for indicator C13; in the case of Finland for indicator C31 data for 2018 were used, and in the case of Germany for indicator C14 the data for 2017 were used. According to available data, the evaluation of ICT usage in enterprises was performed on a sample of 31 countries: Austria, Belgium, Bosnia and Herzegovina, Bulgaria, Croatia, Czech Republic, Cyprus, Denmark, Estonia, Finland, France, Germany, Greece, Hungary, Italy, Ireland, Latvia, Lithuania, Luxembourg, Malta, Netherlands, Norway, Poland, Portugal, Romania, Serbia, Slovakia, Slovenia, Spain, Sweden and the United Kingdom. 
Table 1 Indicators of ICT usage in enterprises

\begin{tabular}{|c|c|c|c|}
\hline Goal & Criteria & Subcriteria & Optimization \\
\hline \multirow{4}{*}{ 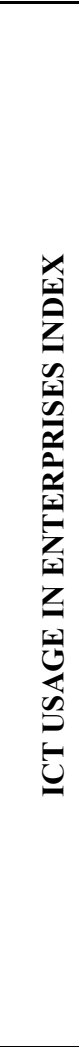 } & $\begin{array}{c}\text { E-commerce } \\
\left(C_{1}\right)\end{array}$ & $\begin{array}{l}\text { Enterprises with e-commerce sales to other EU } \\
\text { countries and the rest of the world }\left(\mathrm{C}_{11}\right) \\
\text { Enterprises with e-commerce sales }\left(\mathrm{C}_{12}\right) \\
\text { Enterprises' total turnover from e-commerce }\left(\mathrm{C}_{13}\right) \\
\text { Difficulties for web sales to other EU countries (of } \\
\text { high costs, complaints, labelling, languages, } \\
\text { business partners restrictions) }\left(\mathrm{C}_{14}\right)\end{array}$ & $\begin{array}{c}\max \\
\max \\
\max \\
\min \end{array}$ \\
\hline & $\begin{array}{c}\text { Connection } \\
\text { to the } \\
\text { internet }\left(\mathrm{C}_{2}\right)\end{array}$ & $\begin{array}{l}\text { Enterprises with internet access }\left(C_{21}\right) \\
\text { Persons employed using computers with access to } \\
\text { www }\left(C_{22}\right) \\
\text { The maximum contracted download speed of the } \\
\text { fastest fixed internet connection is at least } 30 \mathrm{Mb} / \mathrm{s} \text {, } \\
\text { but less than } 100 \mathrm{Mb} / \mathrm{s}\left(\mathrm{C}_{23}\right) \\
\text { Persons employed that were provided with a } \\
\text { portable device that allows a mobile connection to } \\
\text { the internet for business use }\left(\mathrm{C}_{24}\right)\end{array}$ & $\begin{array}{l}\max \\
\max \\
\max \\
\max \end{array}$ \\
\hline & $\begin{array}{c}\text { Websites } \\
\text { and use of } \\
\text { social media } \\
\left(\mathrm{C}_{3}\right)\end{array}$ & $\begin{array}{l}\text { Enterprises with a web }\left(\mathrm{C}_{31}\right) \\
\text { Use enterprise's blog or microblogs }\left(\mathrm{C}_{32}\right) \\
\text { Develop the enterprise's image or market products } \\
\left(\mathrm{C}_{33}\right) \\
\text { Involve customers in development or innovation of } \\
\text { goods or services }\left(\mathrm{C}_{34}\right)\end{array}$ & $\begin{array}{l}\max \\
\max \\
\max \\
\max \end{array}$ \\
\hline & $\begin{array}{c}\text { E-business } \\
\left(C_{4}\right)\end{array}$ & $\begin{array}{l}\text { Enterprises using software solutions like Customer } \\
\text { Relationship Management }(\mathrm{CRM})\left(\mathrm{C}_{41}\right) \\
\text { Enterprises sending e-Invoices, suitable for } \\
\text { automated processing }\left(\mathrm{C}_{42}\right) \\
\text { Buy cloud computing services used over the internet } \\
\left(\mathrm{C}_{43}\right) \\
\text { Use 3D printing }\left(\mathrm{C}_{44}\right)\end{array}$ & $\begin{array}{l}\max \\
\max \\
\max \\
\max \end{array}$ \\
\hline
\end{tabular}

Note: The data used in the analysis apply to all enterprises, without financial sector (10 persons employed or more). All data are given in $\%$.

Source: Prepared by authors based on EUROSTAT.

\subsubsection{Weighting}

One of the important steps in creating composite indicators is the selection of criterion weights and subcriteria. There is a whole set of different methods in the literature for determining weights, and they can all be categorized into two groups: subjective and objective. In order to avoid bias in determining criteria weights, objective method called entropy method, developed by Shannon (1948), was used. The concept of entropy measures the amount of decision information contained by each property.

Entropy method can be applied in the following way: 
Step 1 Normalization of decision matrix:

$$
P_{i j}=\frac{X_{i j}}{\sum_{i=1}^{m} X i j}
$$

where: $X_{i j}$ - value of the $i^{\text {th }}$ subcriterion and $j^{\text {th }}$ alternative; $i$ - subcriteria: $\mathrm{C}_{11}$, $\mathrm{C}_{12}, \ldots \mathrm{C}_{44} ; j$ - alternatives: Austria, Belgium, Bulgaria, Czech Republic,...United Kingdom.

Step 2. Calculation of entropy value:

$$
E_{j}=-t \sum_{i=1}^{m} P_{i j} \times \ln P_{i j}
$$

where: $\mathrm{t}=1 / \operatorname{Ln}(\mathrm{m}) ; m$ - number of alternatives.

Step 3. Computation of entropy weights:

$$
W_{j}=\frac{D_{j}}{\sum_{i=1}^{n} D_{j}}
$$

where: $D j$ is the degree of deviation of essential information for each criterion and can be calculated as follows: $D j=1-E j ; n$-number of subcriteria.

\subsubsection{Aggregation}

The last step in creating composite indices considers the selection of the appropriate aggregation method. A review of previous research aimed at creating composite indices, the most commonly used methods of aggregation are: arithmetic mean, geometric mean and different types of MCDM methods (OECD, 2008). For the purpose of evaluation of ICT usage in enterprise in the European countries, Technique for Order Preference by Similarity to Ideal Solution (TOPSIS) is used. Hwang \& Yoon (1981) developed TOPSIS and it is one of the most popular MultiCriteria Decision Making (MCDM) methods. It is a linear weighting technique, which is used to identify a solution from a finite set of points. TOPSIS presents an index called closeness to the best-ideal solution and remoteness from the worst-ideal solution, in which the alternative with the highest similarity to the best-ideal solution should be chosen (Onat et al., 2016)

TOPSIS is applied in several steps:

Step 1 Normalization of the constructed decision matrix:

$$
R_{i j}=\frac{X_{i j}}{\sqrt{\sum_{j=1}^{n} X_{i j}^{2}}}
$$


where: $X_{i j}$ - value of the $i^{\text {th }}$ subcriterion and $j^{\text {th }}$ alternative; $i$ - subcriteria: $\mathrm{C}_{11}$, $\mathrm{C}_{12}, \ldots \mathrm{C}_{44} ; j$ - alternatives: Austria, Belgium, Bulgaria, Czech Republic,...United Kingdom.

Step 2 Create weighted normalized decision matrix:

$$
W R=W_{j} \times X R_{i j}
$$

where: $X R_{i j}$ - normalized value of the $i^{\text {th }}$ subcriteria and $j^{\text {th }}$ alternative; $W_{j}$ - weight of the $j^{t h}$ criterion obtained by entropy method.

Step 3 Determination of the best and worst ideal solution:

$$
\begin{aligned}
W R_{\text {best }} & =\left\{W R_{b 1}, W R_{b 2}, \ldots W R_{b n}\right\}=\left\{\left(\max W R_{i j} \mid j \in J\right),\left(\min W R_{i j} \mid j \in J^{\prime}\right)\right\} \\
W R_{\text {worst }} & =\left\{W R_{w 1}, W R_{w 2}, \ldots W R_{w n}\right\}=\left\{\left(\min W R_{i j} \mid j \in J\right),\left(\max W R_{i j} \mid j \in J^{\prime}\right)\right\}
\end{aligned}
$$

where: $J$-related to the benefit criteria; $J^{\prime}$ - related to the cost criteria.

Step 4 Calculation of the Euclidean distance of each alternative from the best and worst ideal solution:

$$
\begin{gathered}
d_{i}^{\text {best }}=\sqrt{\sum_{j=1}^{n}\left(W R_{i j}-W R_{b}\right)^{2}} \\
d_{i}^{\text {worst }}=\sqrt{\sum_{j=1}^{n}\left(W R_{i j}-W R_{w}\right)^{2}}(9)
\end{gathered}
$$

where: $W R_{b}$ - the ideal best value; $W R_{b}$ - the ideal worst value.

Step 5. Calculation of the closeness coefficients and ranking the alternatives:

$$
C(I C T E I)=\frac{d_{i}^{\text {worst }}}{d_{i}^{\text {worst }}+d_{i}^{\text {best }}}
$$

where: $0 \leq C(I C T E I) \leq 1$.

\subsection{Cluster analysis}

Cluster analysis groups the observation units into clusters, so that similar observation units are found in the same group or cluster. The distribution of observation units into clusters is done based on a score determined due to the values of all indicators for each observation unit. One of the most commonly used methods for solving clustering problems is the K-means algorithm (Saxena et al. 2017). The procedure for applying the k-means algorithm is based on classifying the dataset into a predefined number of clusters $(\mathrm{k})$. The basic idea is to determine the $\mathrm{k}$ centroid, one for each of the clusters. The objective function $\mathrm{J}$ can be represented as follows: 


$$
\arg \min J=\sum_{j=1}^{k} \sum_{i=1}^{n} \llbracket x_{i}^{(j)}-c_{j} \rrbracket^{2}
$$

where: $\llbracket x_{i}^{(j)}-c_{j} \rrbracket^{2}$ is a chosen distance measure between a data point $x_{i}^{(j)}$ and the cluster center $c_{j}, \mathrm{k}$ - number of clusters, $\mathrm{n}$ - number of cases, $\mathrm{x}_{\mathrm{i}}-$ case $i, c_{j}-$ centroid for cluster $j$.

\section{Results}

\subsection{Creating ICTEI and ranking countries}

The calculated weights based on the entropy method (as described in Section 2 Weighting) indicate that the most significant criteria of ICT usage in enterprises are: $\mathrm{C}_{4}$ and $\mathrm{C}_{1}$, while $\mathrm{C}_{3}$ and $\mathrm{C}_{2}$ are the less important criteria. The most important subcriteria under $\mathrm{C}_{1}$ are: $\mathrm{C}_{14}$ and $\mathrm{C}_{13}$. When it comes to criterion $\mathrm{C}_{4}$, the most important subcriteria are: $\mathrm{C}_{42}$ and $\mathrm{C}_{43}$, while the most important subcriterion for criterion $\mathrm{C}_{3}$ is $\mathrm{C}_{32}$. Lastly, the least important criterion for ICT usage is $\mathrm{C}_{2}$, within which the most important ones are the subcriteria $\mathrm{C}_{24}$ and $\mathrm{C}_{22}$.

Table 2 Relative importance of the criteria and subcriteria

\begin{tabular}{|c|c|c|c|c|c|c|}
\hline Criteria & Weights & Rank & Subcriteria & Local weights & Rank & Global weights \\
\hline \multirow{4}{*}{$\mathrm{C}_{1}$} & \multirow{4}{*}{0.31092} & \multirow{4}{*}{2} & $\mathrm{C}_{11}$ & 0.23456 & 3 & 0.07293 \\
\hline & & & $\mathrm{C}_{12}$ & 0.14039 & 4 & 0.04365 \\
\hline & & & $\mathrm{C}_{13}$ & 0.28290 & 2 & 0.08796 \\
\hline & & & $\mathrm{C}_{14}$ & 0.34218 & 1 & 0.10639 \\
\hline \multirow{4}{*}{$\mathrm{C}_{2}$} & \multirow{4}{*}{0.09829} & \multirow{4}{*}{4} & $\mathrm{C}_{21}$ & 0.00631 & 4 & 0.00062 \\
\hline & & & $\mathrm{C}_{22}$ & 0.24163 & 2 & 0.02375 \\
\hline & & & $\mathrm{C}_{23}$ & 0.16645 & 3 & 0.01636 \\
\hline & & & $\mathrm{C}_{24}$ & 0.58561 & 1 & 0.05756 \\
\hline \multirow{4}{*}{$\mathrm{C}_{3}$} & \multirow{4}{*}{0.22401} & \multirow{4}{*}{3} & $\mathrm{C}_{31}$ & 0.04705 & 4 & 0.01054 \\
\hline & & & $\mathrm{C}_{32}$ & 0.60613 & 1 & 0.13578 \\
\hline & & & $\mathrm{C}_{33}$ & 0.13124 & 3 & 0.02940 \\
\hline & & & $\mathrm{C}_{34}$ & 0.21553 & 2 & 0.04828 \\
\hline \multirow{4}{*}{$\mathrm{C}_{4}$} & \multirow{4}{*}{0.36677} & \multirow{4}{*}{1} & $\mathrm{C}_{41}$ & 0.13098 & 4 & 0.04804 \\
\hline & & & $\mathrm{C}_{42}$ & 0.39289 & 1 & 0.14410 \\
\hline & & & $\mathrm{C}_{43}$ & 0.28574 & 3 & 0.10480 \\
\hline & & & $\mathrm{C}_{44}$ & 0.19037 & 2 & 0.06982 \\
\hline
\end{tabular}

Source: Authors 
Vasilić et al. / Economic Themes, 58(4): 529-544

Table 3 Ranking countries according to ICTEI ${ }^{\text {advanced }}$ and ICTEI ${ }^{\text {equal }}$

\begin{tabular}{|c|c|c|c|c|c|c|c|}
\hline Country & ICTEI $I^{\text {advanced }}$ & Ideals & Rank & ICTEI $I^{\text {equal }}$ & Ideals & Rank & $\begin{array}{c}\text { Difference } \\
\text { in Ranks }\end{array}$ \\
\hline & 0.742876 & 1.00000 & 1 & 0.712975 & 1.00000 & 1 & 0 \\
\hline & 0.571541 & 0.76936 & 2 & 0.60913 & 0.85435 & 3 & -1 \\
\hline 包 & 0.560443 & 0.75442 & 3 & 0.566383 & 0.79439 & 5 & -2 \\
\hline & 0.545353 & 0.73411 & 4 & 0.613125 & 0.85995 & 2 & 2 \\
\hline & 0.513278 & 0.69093 & 5 & 0.573279 & 0.80407 & 4 & 1 \\
\hline & 0.500931 & 0.67431 & 6 & 0.441875 & 0.61977 & 10 & -4 \\
\hline E्य. & 0.485611 & 0.65369 & 7 & 0.533016 & 0.74759 & 7 & 0 \\
\hline & 0.455897 & 0.61369 & 8 & 0.535928 & 0.75168 & 6 & 2 \\
\hline$\sqrt{18}$ & 0.442615 & 0.59581 & 9 & 0.439528 & 0.61647 & 11 & -2 \\
\hline & 0.425087 & 0.57222 & 10 & 0.523904 & 0.73481 & 8 & 2 \\
\hline & 0.42048 & 0.56602 & 11 & 0.415182 & 0.58232 & 14 & -3 \\
\hline & 0.418626 & 0.56352 & 12 & 0.399155 & 0.55984 & 17 & -5 \\
\hline+ & 0.395457 & 0.53233 & 13 & 0.495410 & 0.69485 & 9 & 4 \\
\hline & 0.395306 & 0.53213 & 14 & 0.423140 & 0.59349 & 12 & 2 \\
\hline & 0.36442 & 0.49055 & 15 & 0.419398 & 0.58824 & 13 & 2 \\
\hline & 0.341817 & 0.46013 & 16 & 0.400809 & 0.56216 & 16 & 0 \\
\hline 8 & 0.324473 & 0.43678 & 17 & 0.356611 & 0.50017 & 19 & -2 \\
\hline E & 0.31894 & 0.42933 & 18 & 0.325217 & 0.45614 & 24 & -6 \\
\hline$E$ & 0.303946 & 0.40915 & 19 & 0.352492 & 0.49439 & 20 & -1 \\
\hline & 0.302817 & 0.40763 & 20 & 0.404023 & 0.56667 & 15 & 5 \\
\hline & 0.299331 & 0.40294 & 21 & 0.350349 & 0.49139 & 21 & 0 \\
\hline & 0.294686 & 0.39668 & 22 & 0.332179 & 0.46591 & 23 & -1 \\
\hline & 0.294503 & 0.39644 & 23 & 0.290174 & 0.40699 & 28 & -5 \\
\hline & 0.294499 & 0.39643 & 24 & 0.306842 & 0.43037 & 25 & -1 \\
\hline & 0.280594 & 0.37771 & 25 & 0.303901 & 0.42624 & 26 & -1 \\
\hline & 0.274908 & 0.37006 & 26 & 0.299558 & 0.42015 & 27 & -1 \\
\hline & 0.273068 & 0.36758 & 27 & 0.346429 & 0.48589 & 22 & 5 \\
\hline & 0.270491 & 0.36411 & 28 & 0.269644 & 0.37819 & 30 & -2 \\
\hline & 0.269788 & 0.36317 & 29 & 0.279940 & 0.39264 & 29 & 0 \\
\hline & 0.262382 & 0.35320 & 30 & 0.367952 & 0.51608 & 18 & 12 \\
\hline & 0.253773 & 0.34161 & 31 & 0.242593 & 0.34026 & 31 & 0 \\
\hline
\end{tabular}

Source: Authors. 
After determining the weights of criteria and subcriteria, a multi-criteria analysis is carried out using the TOPSIS approach, as described in Section 3 Aggregation. It is important to note that ranking is done in such a way that advanced ICTs $\left(\mathrm{C}_{4}\right.$ and $\mathrm{C}_{1}$ ) have a priority over basic ICTs $\left(\mathrm{C}_{3}\right.$ and $\left.\mathrm{C}_{2}\right)$. Based on ICTEI $I^{\text {advanced }}$ (Table 3 ), Finland is in the first place in 2019. The following 4 positions occupy: Denmark, Norway, Sweden, and Ireland, respectively. Slovenia, United Kingdom, Netherlands, Spain, Belgium, and Cyprus are ranked at positions 6 through 11, respectively. The last five positions, from 27 to 31, are occupied by Czech Republic, Bulgaria, Hungary, Germany, and Romania, respectively.

Denmark, Norway, and Sweden took distant positions from the leader and obtained, respectively, $76.93 \%, 75.44 \%, 73.41 \%$ of the best assessment value, while Estonia, Greece, Latvia, Bosnia and Herzegovina, Poland, Czech Republic, Bulgaria, Hungary, Germany, and Romania have the worst scores, in the range from $39.66 \%$ to $34.16 \%$ of the leaders' scores.

Since the weights obtained by the entropy method give priority to advanced ICTs $\left(\mathrm{C}_{4}\right.$ and $\left.\mathrm{C}_{1}\right)$, equal weights will also be used in the paper (all criteria of ICT usage are equally proffered) in order to see potential changes in the position of countries with changing importance of ICT usage criteria.

As can be seen in Table 3, based on the obtained ICTEI Iqual values, the first 5 positions are occupied by the same countries, only the distribution of positions has changed somewhat. Finland is still in the lead. Denmark and Norway are in the $3^{\text {rd }}$ and $5^{\text {th }}$ place, respectively, which is worse by 1 and 2 positions, respectively, compared to the previous ranking. Sweden now occupies the $2^{\text {nd }}$ position (climbed for 2 places), and Ireland the $4^{\text {th }}$ position (climbed for 1 place). The largest change of position occurred in the case of Germany (climbed for 12 positions), Slovakia (descended for 6 positions), Czech Republic and Austria (climbed for 5 positions), and Greece and Italy (descended for 5 positions). Apart from Finland, the previous positions were retained by the United Kingdom, Lithuania, Luxembourg, Hungary, and Romania. If we compare the values from the column Ideals between ICTEI Idvanced $^{\text {and }} \mathbf{I C T E I ^ { \text { equal } }}$, it can be noticed that the distance between the leader country and the remaining countries is smaller in the case of ICTEI Iqual $^{\text {eqanking. }}$

\subsection{Clustering countries according to ICT usage in enterprises}

Cluster analysis will identify which countries have significant similarities to the observed ICT usage indicators, so that they can be grouped into appropriate clusters.

First step in cluster analysis is to determine the optimal number of clusters. The optimal number of clusters was determined using the following formula (Ahmed \& Mahmood, 2015; Chiang \& Mirkin, 2010): 


$$
K=\sqrt{\left(\frac{n}{2}\right)}=\sqrt{\frac{31}{2}}=3.94 \approx 4
$$

After selecting the optimal number of clusters, the cases were arranged in clusters using k-means algorithm. In the first step, clustering was performed on the basis of standardized raw data. Results of such a clustering overlap with the results of ICTEI equal , because the results of both methods were dependent only on the same set of statistical data i.e. no weights were used. As can be seen from Figure 1, the first cluster consists of Finland, Denmark, Norway, and Sweden. The second cluster consists of Ireland, Netherlands, Malta, Belgium and United Kingdom; the third cluster Czech Republic, Germany, Estonia, Spain, France, Croatia, Italy, Cyprus, Lithuania, Luxembourg, Austria, Portugal, Slovenia, Serbia, Bosnia and Herzegovina. The remaining fourth cluster includes Bulgaria, Greece, Latvia, Hungary, Poland, Romania, and Slovakia.

Based on the distance from $\mathrm{k}$ centroids between each cluster, it can be concluded that the largest differences exist between the first and the fourth clusters, then the second and the fourth clusters, while the smallest differences exist between the third and the fourth clusters.

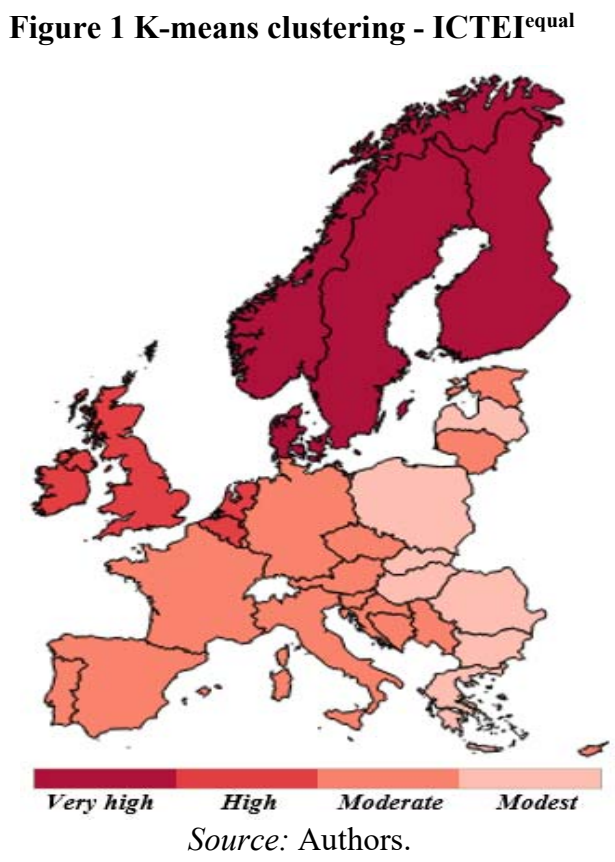

An adjustment of cluster analysis results (presented in Figure 1) needs to be made in accordance with the results of the TOPSIS approach based on the entropy method, 
i.e. ICTEI ${ }^{\text {advanced }}$. When the advanced ICTs are labelled as a priority, Slovenia and Spain move from the third to the second cluster, while Malta and Belgium move from the second to the third one. Czech Republic, Germany, and Bosnia and Herzegovina move from the third to the fourth cluster, while Slovakia, Latvia, and Greece move from the fourth to the third cluster.

Figure 2 Adjusted results of k-means clustering according to ICTEI ${ }^{\text {advanced }}$

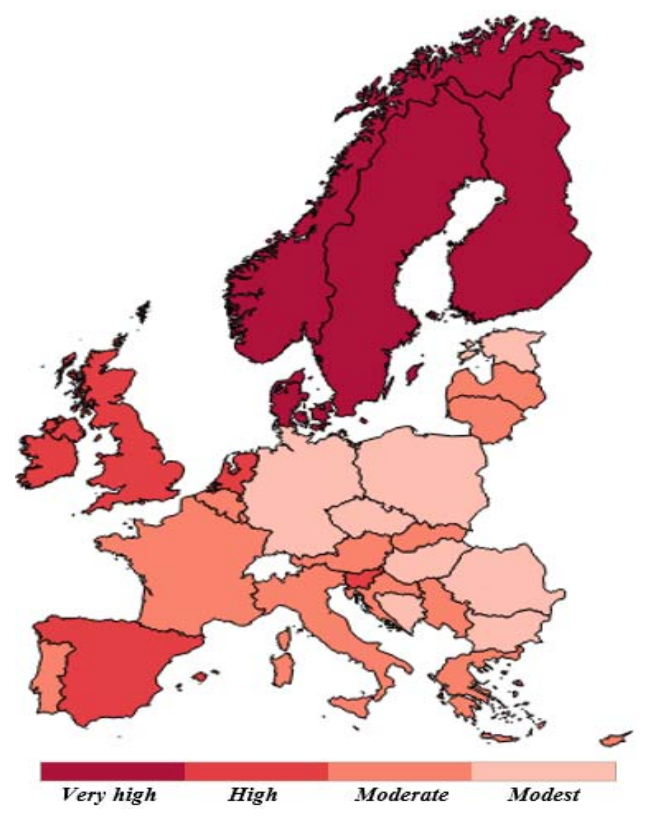

Source: Authors.

\section{Conclusion}

The main objective of the paper was to evaluate ICT usage in enterprises in European countries. For this purpose, ICTEI was developed using the TOPSIS multicriteria analysis method. According to the values of this index, Finland, Denmark, Norway, Sweden, and Ireland are the top 5 countries where advanced ICTs are viewed as priorities, while the Czech Republic, Bulgaria, Hungary, Germany, and Romania occupy the worst positions, respectively. An adjustment of cluster analysis results (presented in Figure 1) needs to be made in accordance with the results of the TOPSIS approach based on the entropy method. That means that if the advanced ICTs are labelled as a priority, Slovenia and Spain move from the third to the second cluster, while Malta and Belgium move from the second to the third one, the Czech Republic, Germany, and Bosnia and Herzegovina move from the third to the fourth cluster, while Slovakia, Latvia, and Greece move from the fourth to the third cluster. 
The policy makers of the countries from the third and the fourth clusters (according to the results of adjusted cluster analysis) need to stimulate the business sector to use ICTs more intensively in order to strengthen their competitive position and economic prosperity of a country as a whole. Special focus in these countries should be on promoting intensive usage of e-commerce and e-business. However, Germany has been unexpectedly found in the cluster of countries with modest ICT use in enterprises, as one of the strongest economies from all the analysed countries, based on ICETI ${ }^{\text {advanced }}$, and in the cluster of countries with a moderate ICT use in companies based on ICTEI ${ }^{\text {equal }}$. Such results are in accordance with the research conducted by Becker et al. (2018). Namely, Becker et al. (2018) came to the conclusion by using the application of the Analytic Network Process (ANP) method and subjective approach in weights determination that Germany is positioned lower than Slovenia, Austria, Slovakia and the Czech Republic when all ICT are treated equally. When focusing on advanced ICT (e-commerce and e-business) Germany ranked lower than Slovenia, Austria, Slovakia and the Czech Republic (Becker et al., 2018). Other economically developed countries such as France, Italy and Austria are in a similar position as Germany and therefore such results require in-depth analysis aimed at the overview of real differences which the application of the mentioned ICT makes, especially advanced ones, on a development level between countries, that is whether and to which extent the use of ICT in question generates economic growth in countries at different levels of development.

The main contribution of the research can be divided in two segments. First, a new methodological approach to evaluating ICT usage in enterprises is developed. The use of ICT usage in enterprises index (ICTEI) will be helpful to policy makers in assessing the ICT capacity of the business sector, especially when the focus is on the advanced ICT. The second part of the research deals with clustering of countries based on previously performed evaluation using entropy based TOPSIS approach. Results of the adjusted cluster analysis allow changes of the cluster members to be observed when advanced ICTs are prioritized. In general, the output of this research will facilitate the perception of the country's position in relation to others, but will also signal the need to take measures to strengthen the ICT capacity of the business sector in the countries with low ICTEI value.

In the future research, it would be useful to include other countries from the Europe in accordance with the availability of data. Also, a basket of indicators used for creating ICTEI could be extended by including additional indicators related to the number of enterprises that analyze big data (this indicator is available for 2018, but not for all countries from the sample) and purchasing online (this indicator is available for 2017), depending on the availability of this data in the following period. 


\section{References}

Ahmed, M., \& Mahmood, A.N. (2015). Novel Approach for Network Traffic Pattern Analysis using Clustering-based Collective Anomaly Detection. Annals of Data Science, 2(1),111130.

Ansari, A., \& Mela, C.F. (2003). E-Customization. Journal of Marketing Research, 40(2),131145.

Arvanitis, S., Loukis, E., \& Diamantopoulou, V. (2013). The effect of soft ICT capital on innovation performance of Greek firms. Journal of Enterprise Information Management, 26(6), 679-701.

Becker, J., Becker, A., Sulikowski, P., Zdziebko, T. (2018). ANP-based analysis of ICT usage in Central European enterprises. Procedia Computer Science, 126, 2173-2183.

Chiang, M.M.T., \& Mirkin, B. (2010). Intelligent Choice of the Number of Clusters in K-Means Clustering: An Experimental Study with Different Cluster Spreads. Journal of Classification, 27, 3-40.

Haseeb, H.M. (2015). The role of ICT management to achieve organizational innovation. The International Journal of Organizational Innovation, 7(4), 48-57.

Hitchen, E.L., Petra, A.N., Ferràs, X., \& Mussons, S. (2017). Social media: open innovation in SMEs finds new support. Journal of Business Strategy, 38(3), 21-29.

Hwang, C.L., \& Yoon, K. (1981). Multiple attribute decision making: Methods and applications. New York: Springer-Verlag.

Jorgensen, D.W., Ho, M.S., \& Stiroh, K.J. (2002). Projecting Productivity Growth: Lesson from the US Growth Resurgence. Federal Reserve Bank of Atlanta Economic Review, 1-13.

Keček, D., Boljunčić, V., \& Milković, M. (2019). Effects of final expenditures on ICT goods and services on the Croatian domestic output and imports - the input-output approach, Economic Research. Ekonomska istraživanja, 32(1), 531-554.doi: 10.1080/1331677X.2018.1556109

Kleis, L., Chwelos, P., Ramirez, R., Cockburn, I. (2012). Information technology and intangible output: the impact of IT investment on innovation productivity. Information Systems Research, 23(1), 42-59.

OECD (2008). Handbook of constructing composite indicators: methodology and user guide.

Onat, N.C., Gumus, S., Kucukvar, M., \& Tatari, O. (2016). Application of the TOPSIS and intuitionistic fuzzy set approaches for ranking the lifecycle sustainability performance of alternative vehicle technologies. Sustainable Production and Consumption, 6, 12-25.

Ongori, H., \& Migiro, S. O. (2010). Information and communication technology adoption: A literature review. Journal of Chinese Entrepreneurship, 2(1), 93-104.

Saxena, A., Prasad, M., Gupta, A., Bharill, N., Patel, O.P., Tiwari, A., Er, M.J., Ding, W., \& Lin, C.T. (2017). A Review of Clustering Techniques and Developments. Neurocomputing. doi: 10.1016/j.neucom.2017.06.053

Smith, K. (2002). Assessing the Economic Impacts of ICT. STEP Report R-01, STEP Group, Oslo.

Spiezia, V. (2011). Are ICT Users More Innovative? An Analysis of ICT-Enabled Innovation in OECD Firms. OECD Journal: Economic Studies.

Shannon, C.E. (1948). The mathematical theory of communication. Bell System Technical Journal, 27, 379-423.

van Ark, B. (2002). Measuring the New Economy: An International Comparative Perspective.Review of Income and Wealth, 48, 1-14. 


\title{
OCENA PRIMENE INFORMACIONIH I KOMUNIKACIONIH TEHNOLOGIJA U EVROPI KORIŠĆENJEM TOPSIS METODE
}

\begin{abstract}
Apstrakt Osnouni cilj rada je da oceni primenu informacionih $i$ komunikacionih tehnologija (IKT-a) u preduzećima u trideset i jednoj zemlji Evrope. Iz tog razloga je razvijen IKT indeks upotrebom TOPSIS metode i metode entropije. Potom su, upotrebom klaster analize, zemlje razvrstane u klastere prema indikatorima upotrebe IKT-a. Rezultati pokazuju da Finska, Danska, Norveška, Švedska i Irska predstavljaju top 5 zemalja kada su napredne internet tehnologije prioritizovane. Na osnovu klasterizacije metodom $k$-srednjih vrednosti, Finska je lider u klasteru izuzetno visoke primene IKT-a u preduzećima, a za njom slede Danska, Norveška i Švedska. Klaster sa visokom primenom IKT-a u preduzećima uključuje Irsku, Holandiju, Sloveniju, Španiju, Ujedinjeno Kraljevstvo. Konačno, zemlje koje karateriše umerena $i$ skromna primena IKT-a razurstane u preostala dva klastera. Rezultati ovog istraživanja će olakšati percepciju pozicije neke zemlje u odnosu na druge, ali će, takođe, ukazati na potrebu da se preduzmu izvesne mere kako bi se ojačao kapacitet IKT-a u biznis sektoru, u zemljama sa niskom vrednošću IKT indeksa.
\end{abstract}

Ključne reči: IKT, primena IKT indeksa u preduzećima (ICTEI), TOPSIS, metoda entropije, višekriterijumsko odlučivanje, klaster analiza.

\section{Authors' biographies}

Nikola Vasilić is junior researcher at the Institute Mihajlo Pupin, Science and Technology Policy Research Center. He is a PhD candidate at the Faculty of Economics, University of Kragujevac, Department of Macroeconomics. His primary areas of interest are science and technology development, innovation, applied econometrics, female entrepreneurship, and SMEs. He is currently involved in the project Enterprise Europe Network financed by the European Commission, which helps SMEs innovate and grow on an international scale.

Dušica Semenčenko is senior scientific associate at the Institute Mihajlo Pupin. She theoretically developed model of action and interaction of investigated factors influencing the state and development of National Innovation System in Serbia (NIS). NIS remains the basic subject of her work, with particular emphasis on the historical and cultural condition of technological development. Narrower fields she specializes in are research and support for the development of female entrepreneurship and education of women entrepreneurs. She is professionally specialized in the field of national technology foresight and the role of governments in science-technology-innovation policy design. She is a lecturer at doctoral studies at the University of Belgrade for the program History of Philosophy, Science, and Technology. She is also an innovation consultant and co-founder and secretary-general of the association Technology and Society. She published more than 100 scientific and professional papers and five books. 
Sanja Popović-Pantić - her professional interests are entrepreneurship, innovation management, association's development, and research \& development. She obtained her PhD degree in female entrepreneurship in 2013. from the Faculty of Economics, University of Belgrade. She has been chairing the Woman's Entrepreneurship Sector Group within the Enterprise Europe Network since May 2015. She is President of the largest national association of female entrepreneurs in Serbia and the international consultant in female entrepreneurship. She also has a respective academic background, as she is employed as Scientific Associate at the Science and Technology Policy Research Center of the Institute Mihajlo Pupin. She is author of three books on entrepreneurship and a number of scientific papers published in national and international journals and proceedings. She was awarded with the "World of Difference 100 Award", by The International Alliance for Women in 2012. She has been awarded by a few national awards as well and one regional for her contributions to the development and promotion of entrepreneurship in the Western Balkans, titled "Creators for Centuries". 